\title{
$E_{\text {ditioria }}$
}

Quando um pesquisador ou estudioso é convidado a proferir uma palestra sobre determinado tema de seu domínio, por mais profundo que seja o seu conhecimento acerca do mesmo, é motivado a buscar novas informações oriundas de estudos recentes. Assim também ocorre certamente na área de Turismo. Tal pesquisador, ao se debruçar tanto sobre temas "consagrados" como Hotelaria, Marketing ou Meio Ambiente, quanto sobre temas cujas informações científicas ainda não são abundantes como Gastronomia, Turismo de Aventura ou Eventos, procurará dar uma abordagem original à sua palestra, destacando novas vertentes de análise, discutindo novas aplicações de modelos ou refletindo sobre a realidade e tendências futuras.

É justamente esse "novo olhar" que se apresenta nos artigos desta edição, em uma clara demonstração do avanço do conhecimento científico em Turismo. Abordando diversos temas, os autores apresentam trabalhos oriundos de estudos e pesquisas desenvolvidos durante a graduação, após esta, e em estudos de pós-graduação ("lato" e "stricto sensu").

Espera-se, portanto, que a leitura atenta e crítica deste número possa despertar nos alunos de graduação o interesse pela pesquisa; nos pósgraduandos, o desenvolvimento de pesquisas científicas de realce e importância no contexto brasileiro; e, nos docentes e profissionais, a aplicação e valorização dos resultados de pesquisas realizadas, mesmo que seja aguçando a sua perspicácia desenvolvida junto ao mercado turístico. 